telopeptide of type I collagen (CTX-I). Dickkopf-related-protein 1 (Dkk-1) and sclerostin were dosed too. For the $\mathrm{HC}$ group, a single blood sample was taken. Results: Neither P1NP nor CTX showed any statistically significant variation. Baseline Dkk-1 for the PsA group was lower than HC. Both Dkk-1 and sclerostin demonstrated a significant increase at the sixth month. When the PsA groups was compared to $\mathrm{HC}$, the difference between the levels of Dkk-1 lost significance at month six.

\begin{tabular}{|c|c|c|c|c|}
\hline & \multicolumn{4}{|c|}{ Healthy controls $(\mathrm{N}=43)$} \\
\hline \multirow{4}{*}{ Sclerostin pmol// } & \multicolumn{4}{|c|}{$25,92 \pm 11,26^{\dagger}$} \\
\hline & \multicolumn{4}{|c|}{$33,11 \pm 16,85$} \\
\hline & \multicolumn{4}{|c|}{ PsA patients $(\mathrm{N}=28)$} \\
\hline & Baseline values (Mean $\pm S D$ ) & month 1 & month 3 & month 6 \\
\hline DAS28 & $3,97 \pm 1,30$ & $3,78 \pm 1,21$ & $3,57 \pm 1,58$ & $3,41 \pm 1,55$ \\
\hline $\mathrm{P} 1 \mathrm{NP} \mathrm{ng} / \mathrm{ml}$ & $43,5 \pm 14,5$ & $-0,31 \pm 12,91$ & $-0,81 \pm 11,97$ & $0,96 \pm 14,87$ \\
\hline CTX ng/ml & $0,25 \pm 0,16$ & $0,02 \pm 0,14$ & $0,04 \pm 0,20$ & $0,08 \pm 0,27$ \\
\hline Dkk-1 pmol/l & $20,0 \pm 13,64$ & $-1,45 \pm 7,89$ & $-1,38 \pm 9,49$ & $2,90 \pm 7,45^{\star}$ \\
\hline Sclerostin pmol// & $30,9 \pm 12,02$ & $-0,76 \pm 8,39$ & $3,09 \pm 7,54^{*}$ & $3,03 \pm 7,77^{\star}$ \\
\hline
\end{tabular}

${ }^{*} p<0,05$ vs baseline, ${ }^{\dagger} p<0,05$ vs Dkk-1 of the PsA group at baseline, month 1 and month 3.

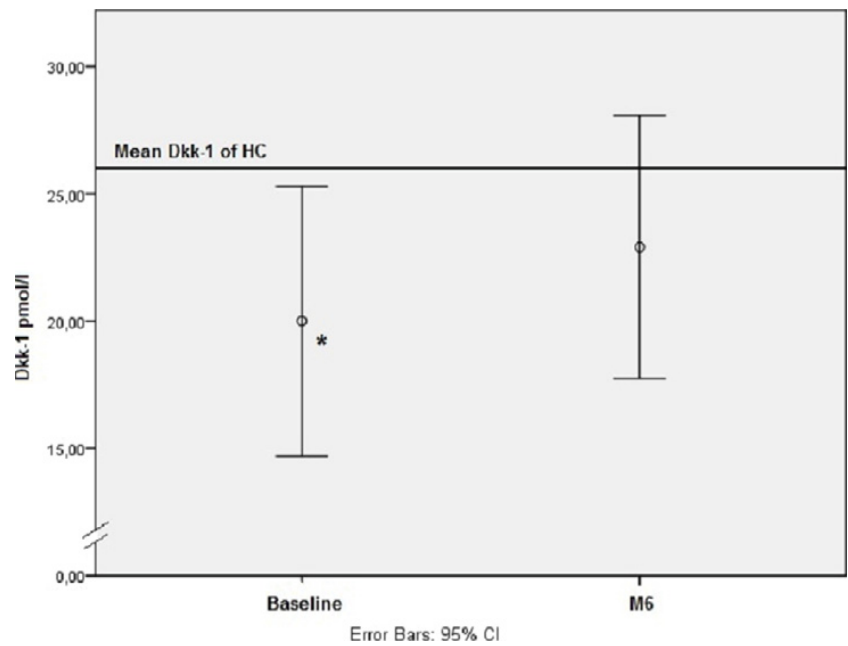

Conclusions: our study demonstrated that the treatment with secukinumab has little influence on the levels of BTM within the first six months of treatment but a definite influence on some fine regulators of the bone cells activity such as the WNT inhibitors and it is able, in some way, to normalize the Dkk-1 levels in PsA patients. The clinical implications of this trend are currently unclear thought it might suggest an drug-induced inhibition of the over-proliferation of bone typical of the joint lesions of PsA. Further studies with greater numbers of patients are warranted to determine whether these preliminary results have clinical relevance. References:

[1] Jandus C, Bioley G, Rivals J-P, et al. Increased numbers of circulating polyfunctional Th17 memory cells in patients with seronegative spondylarthritides. Arthritis Rheum 2008;58:2307-17. doi:10.1002/art.23655.

[2] Uluçkan Ö, Jimenez M, Karbach S, et al. Chronic skin inflammation leads to bone loss by IL-17-mediated inhibition of Wnt signaling in osteoblasts. Sci Transl Med 2016:8:330ra37. doi:10.1126/scitransImed.aad8996.

Disclosure of Interest: None declared

DOI: 10.1136/annrheumdis-2017-eular.2734

\section{SAT0446 IXEKIZUMAB IMPROVES PATIENT-REPORTED OUTCOMES IN PATIENTS WITH ACTIVE PSORIATIC ARTHRITIS AND PREVIOUS INADEQUATE RESPONSE TO TUMOUR NECROSIS FACTOR-INHIBITORS}

A. Kavanaugh ${ }^{1}$, R. Vender ${ }^{2}$, J. Birt ${ }^{3}$, D.H. Adams ${ }^{3}$, O. Benichou ${ }^{3}$, C.-Y. Lin ${ }^{3}$, P. Nash ${ }^{4} .{ }^{1}$ Univ of CA San Diego Health System, la Jolla, United States;

${ }^{2}$ Dermatrials Research Inc., Hamilton, Canada; ${ }^{3}$ Eli Lilly and Company,

Indianapolis, United States; ${ }^{4}$ University of Queensland, Brisbane, Australia

Background: Ixekizumab (IXE), a monoclonal high affinity antibody that selectively targets interleukin-17A, was superior to placebo (PBO) in achieving clinical responses and improving health related quality of life (HRQoL) for psoriatic arthritis (PsA) patients who were biologic-naïve. ${ }^{1}$ Herein, results are presented from a phase 3 trial (SPIRIT-P2; NCT02349295) with IXE in patients with active PsA and previous inadequate response to tumor necrosis factor-inhibitors (TNF-i). Objectives: To explore the impact of IXE on patient reported HRQoL outcomes up to 24 weeks (wks) in patients with active PsA.

Methods: In this phase 3, multicentre, double-blind study, 363 adult patients with active PsA were randomly assigned in the ratio of 1:1:1 to subcutaneous administration of either $80-\mathrm{mg}$ IXE every 4 wks (Q4W; $\mathrm{N}=122$ ) or every 2 wks
(Q2W; $\mathrm{N}=123)$ following a $160-\mathrm{mg}$ starting dose at Wk 0 or PBO $(\mathrm{N}=118)$. All patients entering the study had an inadequate response to one or two TNF-i or were intolerant to TNF-i. At baseline and Wk 24, HRQoL was measured by the Short Form-36 Health Survey (SF-36) Physical Component Summary (PCS) and Mental Component Summary (MCS), European Quality of Life 5 Dimensions Visual Analog Scale (EQ-5D VAS), Work Productivity and Activity Impairment-Specific Health Problem (WPAI-SHP; absenteeism; presenteeism, work productivity, and activity impairment), the itch Numeric Rating Scale (NRS), and the Dermatology Life Quality Index (DLQI). Itch NRS, DLQI, and Psoriasis Area Severity Index (PASI) responses were assessed in patients with baseline psoriatic lesion involving $\geq 3 \%$ body surface area (BSA; $N=203$ ). Treatment comparisons were made by a mixed model for repeated measures for continuous data and by a logistic regression model for categorical data with missing values imputed by nonresponder imputation.

Results: Mean baseline (Wk 0) scores for HRQoL measures indicated impaired physical and mental function, quality of life, and work productivity (Table). At Wk 24, clinical efficacy was shown by $50.6 \%$ and $58.1 \%$ of IXE-treated patients achieving ACR20 and PASI75 responses, respectively. Patients receiving IXE (Q4W or Q2W) reported significantly greater improvements in SF-36 PCS and MCS, EQ-5D VAS, and WPAI-SHP (presenteeism, work productivity, and activity impairment) than patients treated with PBO (Table; $\mathrm{p}<.05$ ). For PsA patients with co-morbid psoriasis ( $\geq 3 \% \mathrm{BSA}$ ), IXE treatment (Q4W or Q2W) resulted in significantly greater improvements in itch NRS and DLQI than PBO treatment (Table; $\mathrm{p}<.001$ ). Finally, $51.5 \%$ of IXEQ4W patients and $50.0 \%$ of IXEQ2W patients reached a DLQI total score of 0 or 1 at Wk 24 , which is significantly greater than patients treated with PBO $(9.0 \%, \mathrm{p}<.001)$.

\begin{tabular}{|c|c|c|c|c|}
\hline & & $\begin{array}{c}\mathrm{PBO} \\
\mathrm{N}=118\end{array}$ & $\begin{array}{c}\text { IXEQ4W } \\
\mathrm{N}=122\end{array}$ & $\begin{array}{c}\text { IXEQ2W } \\
N=123\end{array}$ \\
\hline SF $-36 \mathrm{PCS}^{\mathrm{a}}$ & $\begin{array}{l}\text { Baseline } \\
\text { Change from Baseline }\end{array}$ & $\begin{array}{l}33.9(9.0) \\
3.3(1.4)\end{array}$ & $\begin{array}{l}34.8(8.8) \\
8.9(1.3)^{* * \star}\end{array}$ & $\begin{array}{c}34.3(9.1) \\
8.2(1.2)^{* \pm *}\end{array}$ \\
\hline SF.36 MCS $^{a}$ & $\begin{array}{l}\text { Baseline } \\
\text { Change from Baseline }\end{array}$ & $\begin{array}{c}48.0(13.1) \\
0.9(1.3)\end{array}$ & $\begin{array}{c}49.6(11.3) \\
3.6(1.2)^{\star}\end{array}$ & $\begin{array}{l}49.1(11.5) \\
4.0(1.2)^{\star *}\end{array}$ \\
\hline EQ-5D VAS & $\begin{array}{l}\text { Baseline } \\
\text { Change from Baseline }\end{array}$ & $\begin{array}{c}53.6(20.0) \\
1.8(3.4)\end{array}$ & $\begin{array}{c}53.9(22.4) \\
15.3(3.2)^{\mathrm{m} *}\end{array}$ & $\begin{array}{l}53.9(19.7) \\
12.8(3.0)^{\mathrm{m} *}\end{array}$ \\
\hline WPAI-SHP: Absenteeism ${ }^{b}$ & $\begin{array}{l}\text { Baseline } \\
\text { Change from Baseline }\end{array}$ & $\begin{array}{c}11.9(28.1) \\
4.5(5.0)\end{array}$ & $\begin{array}{c}11.6(26.6) \\
3.7(4.6)\end{array}$ & $\begin{array}{l}8.8(23.2) \\
9.4(4.4)\end{array}$ \\
\hline WPAI-SHP: Presenteeism ${ }^{b}$ & $\begin{array}{l}\text { Baseline } \\
\text { Change from Baseline }\end{array}$ & $\begin{array}{l}40.4(28.8) \\
-7.2(4.9)\end{array}$ & $\begin{array}{l}45.0(25.7) \\
-26.6(4.3)^{* \ldots}\end{array}$ & $\begin{array}{r}36.9(25.0) \\
-24.0(4.1)^{\cdots *}\end{array}$ \\
\hline $\begin{array}{l}\text { WPAI-SHP: } \\
\text { Work Productivity }\end{array}$ & $\begin{array}{l}\text { Baseline } \\
\text { Change from Baseline }\end{array}$ & $\begin{array}{c}41.5(29.6) \\
-4.5(5.4)\end{array}$ & $\begin{array}{r}46.9(26.7) \\
-23.2(4.7)^{* * *}\end{array}$ & $\begin{array}{l}38.8(26.6) \\
-17.6(4.6)^{*}\end{array}$ \\
\hline \multirow[t]{2}{*}{$\begin{array}{l}\text { WPAI-SHP: } \\
\text { Activity Impairment }\end{array}$} & $\begin{array}{l}\text { Baseline } \\
\text { Change from Baseline }\end{array}$ & $\begin{array}{l}54.0(25.8) \\
-14.8(4.1)\end{array}$ & $\begin{array}{c}53.9(24.9) \\
-30.2(3.9)^{* t *}\end{array}$ & $\begin{array}{r}49.3(26.5) \\
-26.2(3.7)^{* *}\end{array}$ \\
\hline & & $\mathrm{N}=67$ & $\mathrm{~N}=68$ & $\mathrm{~N}=68$ \\
\hline Itch NRS b.c & $\begin{array}{l}\text { Baseline } \\
\text { Change from Baseline }\end{array}$ & $\begin{array}{l}5.7(2.8) \\
-1.2(0.5)\end{array}$ & $\begin{array}{c}5.5(2.5) \\
-3.4(0.4)^{m * n}\end{array}$ & $\begin{array}{c}5.6(3.0) \\
-3.5(0.4)^{\mathrm{mm}}\end{array}$ \\
\hline DLQ|b,c & $\begin{array}{l}\text { Baseline } \\
\text { Change from Baseline }\end{array}$ & $\begin{array}{l}9.6(8.1) \\
-3.1(0.9)\end{array}$ & $\begin{array}{c}9.1(7.4) \\
-7.7(0.8)^{* \ldots}\end{array}$ & $\begin{array}{c}9.2(7.8) \\
-7.3(0.8)^{* * *}\end{array}$ \\
\hline
\end{tabular}

Baseline values are mean (SD); Change from baseline values are least squares mean (SE).

Increase in score represents improvement

becrease in score represents improvement

'Patients were from the intent-to-treat population with ${ }^{3} 3 \%$ BSA at baseline

"p<.05;" ${ }^{*} p<.01 ;{ }^{* \cdots} p<.001$; with respect to placebo control; $p$-values are from a repeated measures mixed model

Conclusions: In patients with active PsA and previous inadequate response to TNF-i, IXE provided significant improvement through 24 wks in all joint and skin associated HRQoL outcomes, including physical and mental function, quality of life, work productivity, DLQI, and itch.

References:

[1] Mease $P$ et al. 2017 ARD 76(1):79.

Disclosure of Interest: A. Kavanaugh Consultant for: Eli Lilly and Company, R. Vender Grant/research support from: Abbvie, Amgen, Centocor, Dermira, Galderma, GSK, Leo, Eli Lilly and Company, Takeda, Novartis, Merck, Pfizer, Regeneron, Consultant for: Abbvie, Amgen, Janssen, Galderma, GSK, Leo, Eli Lilly and Company, Novartis, Pfizer, Valeant, Actelion, Celgene, Cipher, Palladin, Speakers bureau: Abbvie, Amgen, Janssen, Galderma, GSK, Leo, Eli Lilly and Company, Novartis, Pfizer, Valeant, Actelion, Celgene, Cipher, Palladin, J. Birt Shareholder of: Eli Lilly and Company, Employee of: Eli Lilly and Company, D. Adams Shareholder of: Eli Lilly and Company, Employee of: Eli Lilly and Company, O. Benichou Shareholder of: Eli Lilly and Company, Employee of: Eli Lilly and Company, C.-Y. Lin Shareholder of: Eli Lilly and Company, Employee of: Eli Lilly and Company, P. Nash Grant/research support from: AbbVie, Amgen, BMS, Celgene, Eli Lilly and Company, Hospira, MSD, Pfizer, Janssen, UCB, Novartis, Roche, Sanofi, Consultant for: AbbVie, Amgen, BMS, Celgene, Eli Lilly and Company, Hospira, MSD, Pfizer, Janssen, UCB, Novartis, Roche; Sanofi, Speakers bureau: AbbVie, Amgen, BMS, Celgene, Eli Lilly and Company, Hospira, MSD, Pfizer, Janssen, UCB, Novartis, Roche, Sanofi

DOI: 10.1136/annrheumdis-2017-eular.1580 